\title{
CHILDCARE AND EDUCATION QUALITY ASSURANCE AT PRIVATE PRESCHOOLS: A CASE STUDY IN HANOI, VIETNAM
}

\section{Thao Bich Thi Nguyen}

\section{Article History}

Received: 11 October 2020

Accepted: 8 November 2020

Published: 30 December 2020

\section{Keywords}

Private preschool, childcare, quality assurance

\author{
Preschool Education Department - Vietnam's Ministry of Education and Training \\ Email:ntbthao@moet.gov.vn
}

\section{INTRODUCTION}

Preschool Education (PrE) receives meticulous attention from Vietnam's Government with specific guidelines as an integral part of general education system, the basis of physical, intellectual, emotional, aesthetic, and personality development of preschool children. It is responsibility of all levels of governments, all fields, all families and the whole society to foster Preschool Education development, guaranteeing the opportunities to access high-quality, equal and fair nursery education of each and every child. The State is responsible for managing and developing PrE, establishing mechanism and policies to promote community's participation and social mobilization to develop PrE (Prime Minister, 2018). Thus, state kindergarten system attracts careful attention and welcomes robust changes in managements and improvements in education efficiency. However, as a result of vigorous social participation in PrE, private preschools have made essential contribution to the education and training system, guaranteeing the equal education access for all children and providing various high-quality educational services and environment. Among the underlying causes of those achievements is the Ministry of Education and Training's policies on PrE development in general and concerning quality assurance in particular (MoET, 2018).

It is a matter of fact that PrE, especially private preschools, encounters considerable challenges and disadvantages, among which lies the insufficient assurance of childcare and education quality. Khoi Minh (2017) also states several limitations during operation at some preschools.

Therefore, this paper focuses on examining the situation of quality assurance in childcare and education at preschools through a case study in Hanoi, Vietnam, thereby proposes some policy recommendations related to quality assurance management in preschools in Hanoi in general and private kindergartens in particular.

\section{LITERATURE REVIEW}

Preschool Education quality assurance is the research topic of numerous international studies, namely Becca et al. (2020), McCrea, N. L. and Piscitelli, B. (1991); Chan, L. K., \& Chan, L. (2003). McCrea \& Piscitelli (1991) highlight the quality of preschool educational programs as key content and subjects in assuring PrE quality, including teaching contents, learning experience quality, interaction models between teaching staff and children, and teachers' competency. Yoshikawa et al. (2013) point out the need to establish the quality standards of childcare and preschool education as well as develop procedures and mechanism to enhance childcare and preschool education quality. Becca Merrill et al (2020) recommend building a new quality culture of preschool education by promoting professional competencies and intensify the quality assurance mechanism.

In Vietnam, despite the absence of the key words 'quality assurance' in the existing literature, a number of research works actually focus on very-much-related issues concerning assuring the quality of childcare and preschool education (Le Thi Thu Ba, 2012; Dalli C et al., 2011; Phan Van Kha, 2014; Tran Thi Bich Tra, 2001; Nguyen Thi 
Bich Thao, 2020; Yoshikawa H., et al., 2013; Lloyd Megan Millenkfy, 2010). Assuring quality of nurturing and educating preschool children is defined as activities to maintain, renovate and enhance the quality of childcare and preschool education (Nguyen Thi Bich Thao, 2020; Dang Hong Phuong, 2017). Le Thi Thu Ba (2012) mentions the contents of quality assurance at preschools, including: establishing quality standards of preschools; developing preschools' quality procedures; defining assessment criteria to evaluate childcare and education quality at preschools; managing conditions to assure childcare and education quality; developing quality culture in preschools; managing community's participation in preschools' activities. The local studies are generally in line and supported by international research regarding both research approach and topics.

Given the research background, the questionnaire survey aiming to examine the situation of preschools' quality assurance is designed with following key contents: defining quality standards, developing quality assurance system; developing quality assurance procedure, supporting conditions; community's participation; quality culture.

\section{RESEARCH METHODS AND RESULTS}

\subsection{Methods, subjects and scope of the research}

In the research, the survey questionnaire is employed with 188 managing staff and 368 preschool teachers in several preschools in the districts of Hoang Mai, Thanh Xuan, Long Bien and Dong Anh, Hanoi city between July and September of 2020. The questionnaire was directly distributed to participants (including principles, vice principles, heads of departments, and teachers).

The questionnaire aiming to investigate the situation of assuring quality of childcare and education at preschools consists of 21 questions, divided into the following sections:

1) Defining quality standards for preschools' childcare and education (04 items);

2) Developing the quality assurance system (5 items);

3) Developing the quality assurance procedure (03 items);

4) Financial and infrastructure conditions for assuring quality of childcare and education (03 items);

5) Community's participation in preschools' activities (03 items);

6) Developing culture for preschools' childcare and education quality (03 items).

The Linkert scale is used to design the questionnaire with 5 levels: Very good, good, fair, medium, and weak to evaluate the situation of assuring quality of childcare and preschool education at the selected private preschools.

The data collected are classify using tables and percentages by categories for all research contents with the 5 levels for comparison and contrast. Eventually, the evaluation and judgments regarding the situation of quality assurance in nurturing and educating children at these preschools would be obtained.

\subsection{Research results}

The survey results are presented in the following table.

Table 1. Results of evaluating the preschools' childcare and education quality assurance situation

\begin{tabular}{|c|c|c|c|c|c|c|c|c|c|c|}
\hline \multirow{3}{*}{ Content } & \multicolumn{10}{|c|}{ Results } \\
\hline & \multicolumn{2}{|c|}{ Very good } & \multicolumn{2}{|c|}{ Good } & \multicolumn{2}{|c|}{ Fair } & \multicolumn{2}{|c|}{ Medium } & \multicolumn{2}{|c|}{ Weak } \\
\hline & Number & $\%$ & Number & $\%$ & Number & $\%$ & Number & $\%$ & Number & $\%$ \\
\hline \multicolumn{11}{|c|}{ 1. Defining quality outcomes for preschools' childcare and education } \\
\hline $\begin{array}{l}\text { 1.1. Declaring the } \\
\text { missions and visions as } \\
\text { well as core values of } \\
\text { the preschool }\end{array}$ & 228 & 41,0 & 167 & 30,0 & 136 & 24,5 & 25 & 4,5 & 0 & 0,0 \\
\hline $\begin{array}{l}\text { 1.2. Objectives of } \\
\text { outcome establishing }\end{array}$ & 251 & 45,1 & 158 & 28,4 & 125 & 22,5 & 22 & 4,0 & 0 & 0,0 \\
\hline $\begin{array}{l}\text { 1.3. Planning and policy } \\
\text { building }\end{array}$ & 104 & 18,7 & 182 & 32,7 & 163 & 29,3 & 107 & 19,2 & 0 & 0,0 \\
\hline $\begin{array}{l}\text { 1.4. Implementing } \\
\text { outcome-based } \\
\text { evaluation }\end{array}$ & 120 & 21,6 & 133 & 23,9 & 175 & 31,5 & 128 & 23,0 & 0 & 0,0 \\
\hline \multicolumn{11}{|c|}{ 2. Developing quality assurance system for preschools' childcare and education } \\
\hline $\begin{array}{l}\text { 2.1. Developing and } \\
\text { managing strategic goals }\end{array}$ & 130 & 23,4 & 172 & 30,9 & 147 & 26,4 & 93 & 16,7 & 14 & 2,5 \\
\hline
\end{tabular}


2.2. Adjusting goals and plans based on collected knowledge and $\begin{array}{llllllllll}158 & 28,4 & 165 & 29,7 & 138 & 24,8 & 86 & 15,5 & 9 & 1,6\end{array}$ information

2.3. Improving the childcare and education quality assurance $150 \quad 27,0$ procedure

2.4. Inspection and supervision of managing organisations over

30,8

childcare and education quality assurance

2.5. Parents' and society's supervision

$\begin{array}{llllll}183 & 32,9 & 125 & 22,5 & 128 & 23,0\end{array}$

3. Developing procedure of preschools' childcare and education quality assurance

3.1. Procedure of input quality assurance (regarding recruitment, preschool education program, teaching staff, $211 \quad 37,9 \quad 125$ 22,5 153 27,5 55

9,9

12 2,2 facilities, financial resources, etc.) 3.2. Procedure of processive quality assurance (preschools' managing system, 174 31,3 . educational activities; resources exploitation) 3.3. Procedure of output quality assurance (children's and preschools' development, 227 $40,8 \quad 123 \quad 22,1$ 147 $26,4 \quad 51$ $9,2 \quad 8$ 1,4 social benefits)

\begin{tabular}{|c|c|c|c|c|c|c|c|c|c|c|}
\hline \multicolumn{11}{|c|}{ 4. Financial and infrastructure conditions for assuring quality of preschools' childcare and education } \\
\hline 4.1. Facilities & 187 & 33,6 & 144 & 25,9 & 158 & 28,4 & 46 & 8,3 & 21 & 3,8 \\
\hline $\begin{array}{l}\text { 4.2. Financial } \\
\text { mechanism }\end{array}$ & 165 & 29,7 & 155 & 27,9 & 163 & 29,3 & 51 & 9,2 & 22 & 4,0 \\
\hline 4.3. Managerial condition & 227 & 40,8 & 133 & 23,9 & 168 & 30,2 & 17 & 3,1 & 11 & 2,0 \\
\hline \multicolumn{11}{|c|}{ 5. Community's participation in preschools' activities } \\
\hline $\begin{array}{l}\text { 5.1. Planning of } \\
\text { community's } \\
\text { participation }\end{array}$ & 149 & 26,8 & 151 & 27,2 & 189 & 34,0 & 49 & 8,8 & 18 & 3,2 \\
\hline $\begin{array}{l}\text { 5.2. Identifying the } \\
\text { subject of community's } \\
\text { participation }\end{array}$ & 171 & 30,8 & 137 & 24,6 & 191 & 34,4 & 41 & 7,4 & 16 & 2,9 \\
\hline $\begin{array}{l}\text { 5.3. Implementing } \\
\text { community's } \\
\text { participation plans }\end{array}$ & 148 & 26,6 & 140 & 25,2 & 196 & 35,3 & 38 & 6,8 & 34 & 6,1 \\
\hline \multicolumn{11}{|c|}{ 6. Developing culture for preschools' childcare and education quality } \\
\hline $\begin{array}{l}\text { 6.1. Roles of quality } \\
\text { culture in preschools' }\end{array}$ & 191 & 34,4 & 144 & 25,9 & 160 & 28,8 & 48 & 8,6 & 13 & 2,3 \\
\hline
\end{tabular}


childcare and education

quality assurance

\begin{tabular}{|c|c|c|c|c|c|c|c|c|c|c|}
\hline $\begin{array}{l}\text { 6.2. Values of quality } \\
\text { culture }\end{array}$ & 189 & 34,0 & 141 & 25,4 & 163 & 29,3 & 42 & 7,6 & 21 & 3,8 \\
\hline $\begin{array}{l}\text { 6.3. Applying quality } \\
\text { culture in preschools }\end{array}$ & 136 & 24,5 & 139 & 25,0 & 173 & 31,1 & 75 & 13,5 & 33 & 5,9 \\
\hline
\end{tabular}

It can be observed from the results that:

1) Regarding the situation of developing outcomes of preschools' childcare and education quality

The items 'Objectives of outcome establishing' and 'Declaring the missions and visions as well as core values of the preschool' received positive results with 73,5\% and 71\% of surveyors opting very Good and Good respectively, while the item 'Planning and policy building' and 'Implementing outcome-based evaluation' gained smaller figures for these two levels, at only $51,4 \%$ and $45,5 \%$. The table also pointed out that these two items of 'Planning and policy building' and 'Implementing outcome-based evaluation' were claimed to be 'fair' and 'medium' by higher proportion of participants than others (19,2\% and $23 \%$ respectively).

It can be implied that there is still a lack of concern about preschools' missions, visions and core values as well as objectives of outcome establishing among the participating managers and teachers. Particularly, planning and policy building together with implementing outcome-based evaluation are considerably limited in the surveyed preschools.

2) Regarding developing preschools' childcare and education quality assurance system

The survey findings show that in this section, 'Parents' and society's supervision' was claimed to be 'very good' with the highest percentages of surveyors, $32,9 \%$, while the lowest proportion belonged to 'Improving the childcare and education quality assurance procedure'. All 5 items received the 'good' level with the percentages ranging from $22.5 \%$ to $30.9 \%$. However, the item 'Inspection and supervision of managing organisations over childcare and education quality assurance' was rated rather negatively as 'medium and weak' by a fairly high percentage of the managers and preschool teachers $(22.8 \%)$.

The figures highlight the need to focus on the inspection and supervision from relevant authorities in developing preschools' childcare and education quality assurance. Plus, it's advisable to enhance parents' and society's supervision over preschools' quality assurance and renovate the contents of preschools' childcare and quality assurance.

3) Regarding developing procedure of preschools' childcare and education quality assurance

The procedure of preschools' childcare and education quality assurance covers the assurance over the quality of input, process and outputs. The procedure of input quality assurance (regarding recruitment, preschool education program, teaching staff, facilities, financial resources, etc.) received considerably more positive feedback from participants than the other two items, claimed to be 'very good' by $40.8 \%$ of all surveyors. All three items were rated as 'good' with the percentages ranging from $22.1 \%$ to $26.6 \%$. Regarding the levels of 'medium' and 'weak', the percentages for all three contents are quite similar around 10\%. Despite of the limitation (about $40 \%$ of participants chose the level 'fair' and below), the development of procedure of preschools' childcare and education quality assurance is believed to fulfill the existing requirements.

4) Regarding financial and infrastructure conditions for assuring quality of preschools' childcare and education

In this section, the survey results show that managerial conditions were evaluated 'very good' by the most participants (40.8\%) while the other two items were rated 'very good' by $29.7 \%$ and $33.6 \%$. All 3 contents were rated 'good' by $23.9 \%$ to $26 \%$ of all the participants. It can be seen that the teaching facilities and equipment at surveyed preschools were invested with adequate resources to meet the minimal requirements. On the other end, that $30 \%$ of the participants chose 'fair', over 5\% chose medium and 13\% chose 'weak' calls for a solution of infrastructure investment and financial mechanism to enhance the assurance of preschools' childcare and education quality.

5) Regarding Community's participation in preschools' activities

Community's participation in preschools' activities is the essential prerequisite to improve the quality of childcare and education as well as the preschool's development. There are three main contents of community's participation, namely: Planning of community's participation; Identifying the subject of community's participation; Implementing community's participation plans.

The first content was evaluated 'very good' and 'good' by a combining $56 \%$ of the surveyors, while the second one by $55.4 \%$ and the last by $51.8 \%$. The figures demonstrate the attention and achievement of the selected preschools 
in promoting community's participation. However, there were still $35 \%$ of participants choosing 'fair' and over $10 \%$ rating medium and weak considering these factors.

6) Regarding developing culture for preschools' childcare and education quality

Quality culture ensure the sustainability of quality assurance in preschools due to the fact that only by developing quality culture can quality assurance be effective. Developing quality culture is a must to assure quality, concerning three main contents (in the scope of this study) namely building culture of childcare and education quality, values of quality culture and applying quality culture in preschools.

It can be seen from the table that the content' Applying quality culture in preschools' was evaluated 'very good' by the fewest participants, only $24.5 \%$ while the figures for the other two items were $34.4 \%$ and $34 \%$. In contrast, the most surveyors chose medium and weak for the item 'Applying quality culture in preschools' at $13.5 \%$ and $5.9 \%$ respectively. The results highlights the requirement for the preschools to emphasize the role of quality culture and its values in childcare and educational activities; as well as to adopt measures to apply quality culture in preschools in order to improve preschools' childcare and education quality assurance.

\section{DISCUSSION AND CONCLUSION}

Preschools' childcare and education quality assurance is vital. The research findings reveal the varied situations of childcare and education quality assurance in the selected preschools in Hanoi. The results are significant in proposing solutions to improve preschools' childcare and education quality assurance. This study leads the author to give some suggestions on the educational management in preschool in some cities in Vietnam. Preschool needs to pay more attention to building the school culture and defining the mission, vision and core values.

\section{REFERENCES}

Chan, L. K., \& Chan, L. (2003). Early Childhood Education in Hong Kong and its Challenges. Early Child Development and Care, 173(1), 7-17. DOI: 10.1080/0300443022000022387

Dalli C., White E., Rockel J., \& Duhn, I. (2011). Quality ECE for under-two year olds: What should it look like? A literature review. New Zealand: Report to the Ministry of Education.

Dang, H. P. (2017). Preschool Education Quality in Vietnam in the era of international integration: Situation and Implications. Vietnam Journal of Education, Special Volume 12/2017, 130-132.

Khoi Minh (2017). Supervising quality of private preschools. Today Magazine (an edition of People Magazine) issued 14/1/2017. Retrieved from: https://nhandan.com.vn/baothoinay-dothi/siet-chat-luong-truong-mam-nontu-thuc-311931

Le, T. T. B. (2012). Managing childcare and education quality at private preschools in Ho Chi Minh city, Vietnam. Doctorate Dissertation, Vinh University.

Lloyd Megan Millenkfy (2010). The key role of staff in providing quality preschool education.

McCrea, N. L. \& Piscitelli, B. (1991). Handbook of High-Quality Criteria for Early Childhood Programs (rev. ed.). Brisbane, Queensland: QUT.

Merrill, B. et al. (2020). "Quality" assurance features in state-funded early childhood education: A policy brief. Children and Youth Services Review, 113, 104972. https://doi.org/10.1016/j.childyouth.2020.104972

Ministry of Education and Training (2018). Regulations on education quality assessment and recognition of national standard fulfilment with preschools (issued with Circular No 19/2018/TT-BGDDT of MoET).

Nguyen, T. B. T. (2020). Awareness of managers and teachers at private preschools in Hanoi about childcare and education assurance. Journal of Science, Vinh University, 49, Issue 3B/2020, 57-63.

Nguyen, T. B. T. (2020). Developing the rapport between preschools and parents in childcare and education at private preschool: Situation and Solutions. Vietnam Journal of Education, Special Volume 2, November 2020.

Phan, V. K. (2014). Vietnam's education management reform: Theory and Practice. Hanoi National University Publishing House.

Prime Minister (2018). Decision No 1677/QD-TTg dated 03/12/2018 of the Prime Minister approving the Preschool Education Development in the period 2018-2025.

Tran, T. B. T. (2001). Recommendations to foster childcare and education quality at non-state preschools. Ministrylevel scientific project, Code B2000-52- 46. Institute of Education Strategies and Programs.

Yoshikawa, H. et al. (2013). Investing in our future: The evidence base on preschool education. New York, NY: Foundation for Child Development. 